\title{
PREVALENCE OF SURGICAL AFFECTIONS OF CATTLE IN AARONG DAIRY AREA OF PABNA
}

\author{
A. S. M. Noman, N. S. Juyena ${ }^{1}$, M. M. Alam, R. N. Ferdousy, S. Paul and \\ M. M. Haq \\ Department of Surgery and Obstetrics, Bangladesh Agricultural University \\ Mymensingh-2202, Bangladesh
}

\begin{abstract}
AARONG dairy area of Pabna comprises a major part to meet the demand of milk and meat production in Bangladesh. Various diseases including surgical affections reduce the fitness, efficiency and productivity of cattle in this area. There is a need to investigate the occurrence of surgical diseases to take proper preventive measures. Therefore, the prevalence of surgical affections of cattle was studied in four Upazilas of Pabna from December 2012 to May 2013. A total of 2390 cattle from different households were included and surgical affections were recorded. The overall prevalence was $44.3 \%$ in stall feeding system, among which surgical affections were more prevalent in Sujanagar Upazilas (13.3\%), and the highest prevalent surgical affection was foot diseases $(8.2 \%)$ followed by navel ill (6.3\%), myiasis $(4.6 \%)$, arthritis, hernia and wounds (3.6\%). Overall prevalence of surgical affections was slightly higher in female cattle in comparison to males The prevalence of navel ill $(11.3 \%)$, foot disease $(11.1 \%)$, hernia $(6.1 \%)$ and horn affections $(4.9 \%)$ were found to be higher in male. Whereas, myiasis $(5.9 \%)$, upward patellar fixation $(2.8 \%)$ were found to be higher in females. There is significant $(\mathrm{P}<0.01)$ difference in the prevalence of hernia, upward patellar fixation, horn affection, foot diseases and myiasis between male and female. It was also observed that cattle of 0-1 year was affected more frequently with surgical affections $(18.7 \%)$ among which prevalence of navel ill $(15.5 \%)$, hernia $(8.3 \%)$, myiasis $(5.4 \%)$ and foot diseases $(5.3 \%)$ were higher. In addition, foot disease was more prevalent surgical affection in cattle of more than one year. Moreover, significant variation $(\mathrm{P}<0.01)$ was existed in the prevalence of upward patellar fixation, foot diseases, arthritis and wounds among three age groups. However, results of the present study indicate that there is a strong relation among the prevalence of surgical affections, sex and age of animals. Moreover, foot disease is a common occurrence in stall feeding cattle in Pabna.
\end{abstract}

Key Words: Surgical affections, Aarong dairy area, Cattle

\section{INTRODUCTION}

Livestock plays an important role in the national economy of Bangladesh. AARONG area of Pabna belt is the harbour of milk in Bangladesh, and this area is densely populated by cattle

\footnotetext{
${ }^{1}$ Associate Professor, Department of Surgery and Obstetrics, Bangladesh Agricultural University, Mymensingh-2202, Bangladesh

*Corresponding author (Email: juyenahabib@yahoo.com)
} 
heads (Sarker, 2012). Milk is an ideal food as it contains all the food constituents and is indispensible for growth and maintenance of health. According to the World Bank (2012), the increased growth rate of population and rapid change of life style has focused a tremendous demand of milk and meat. To meet up the increasing demand of milk, commercial dairy farming is emerging as an important livestock enterprise and health management of cattle is prerequisite for maximum production of quality milk from a cow. But surgical affections hinder the growth and performance, major threats for our economy if proper surgical measures are not taken (Samad, 1998, Sultana, 2011). The leading surgical anomalies hindering the growth and performance are hernia, atresia ani, navel ill, myiasis, gangrenous mastitis, teat obstruction, teat crack, foot diseases and lameness (Hossain et al., 1986 and Samad, 1998). Failure of surgical treatment to patients provides no alternative except the culling (Berge et al, 1986).It is important that a hypothetical survey is necessary to bring basic data for further study of surgical affections and thereby solve the problem in Bangladesh. A few works on surgical affections in cattle were done in Bangladesh (Samad, 2000). However, there is no previous data on the prevalence of surgical affections in cattle of Aarong Dairy area of Pabna. For this reason, this study has been carried out to find the prevalence of surgical affections and to investigate effects of age and sex on the occurrence of major surgical affections of cattle in four Upazilas of Pabna.

\section{METHDOLOGY}

This study was conducted in four Upazilas of Pabna (Santhia, Bera, Faridpur and Sujanagor) to investigate the prevalence of surgical affections of cattle in Aarong area of Pabna. The data were collected randomly and a total of 2390 cattle were included in this study. Cross sectional study was performed to find out the prevalence of surgical affections in cattle. The housing and feeding system were observed. Cattle were reared in stall feeding system (Indoor farming system). Owner and handler were asked to know the history of surgical affections and the affected and non-affected animals examined to confirm the affections. The clinical examination was done by visual inspection of gait, posture of cattle, and palpation of the affected area, needle pricking and percussion of the organs. Sex and age were considered as variables for analyzing data. Distribution of surgical affections among variable was done by observing the cattle, history and clinical examination.

The prevalence of surgical affections in the affected area was calculated by following formula.

$$
\text { Prevalence }=\frac{\text { Number of surgical affected cattle }}{\text { Total examined cattle }} \times 100
$$

The statistical analysis was performed using MSTAT-C software and SPSS system. DMRT (Dancan's Multiple Range Test) and CRD F-test was used to determine the significant difference. P-value $<0.05$ was considered as significant level.

\section{RESULTS AND DISCUSSION}

The status of herd health depends on surgical affections, infectious diseases, gynaecological affairs and so on. Among them surgical affections are the front line problems of farmers 
(Samad, 1998). There is indeed a need for identification of common surgical problems that reduce the fitness and efficiency of cattle and hinder profitability in commercial farms. Therefore, the study was aimed to find out the prevalence of surgical problems.

The prevalence of surgical affections of stall fed cattle in four Upazilas of Aarong belt is presented in Table 1 and Fig. 1 and Fig. 2. The overall prevalence was $44.3 \%$ in stall feeding system, among which surgical affections were more prevalent in Santhia and Sujanagar Upazilas (13.1\%, 13.3\% respectively (Fig. 2) and less in Foridpur Upazila (7.8\%) (Fig. 1). In stall feeding system, the highest prevalent surgical affections was foot diseases $(8.2 \%)$ followed by navel ill (6.3\%), myiasis (4.6\%), arthritis, hernia and wounds (3.6\%). Hossain et al. (1986) and Samad (1998) also found that the leading surgical anomalies hindering the growth and performance were hernia, atresia ani, navel ill, myiasis, gangrenous mastitis, teat obstruction, teat crack, foot diseases and lameness. The prevalence of congenital surgical diseases was negligible (Table 1). One of the reasons behind this condition is probably the practice of artificial insemination among local and high yielding varieties (Slatter, 1985 and Hossain, 2011). According to this assumption, use of good quality semen and healthy dam may show positive result on the absence of atresia ani.

Table 1. Prevalence (\%) of surgical affections of cattle in four Upazilas

\begin{tabular}{l|c|c|c|c|c|c|c|c}
\hline \multirow{2}{*}{ Surgical affections } & \multicolumn{2}{c}{$\begin{array}{c}\text { Santhia } \\
\mathrm{n}=620\end{array}$} & \multicolumn{2}{c}{$\begin{array}{c}\text { Bera } \\
\mathrm{n}=560\end{array}$} & \multicolumn{2}{c|}{$\begin{array}{c}\text { Sujanagor } \\
\mathrm{n}=780\end{array}$} & \multicolumn{2}{c}{$\begin{array}{c}\text { Foridpur } \\
\mathrm{n}=430\end{array}$} \\
\cline { 2 - 9 } & No. & $(\%)$ & No. & $(\%)$ & No. & $(\%)$ & No. & $(\%)$ \\
\hline Hernia & 25 & $\mathbf{4 . 0}$ & 18 & $\mathbf{3 . 2}$ & 26 & $\mathbf{3 . 3}$ & 16 & $\mathbf{3 . 7}$ \\
Atresia ani & 5 & $\mathbf{0 . 8}$ & 2 & $\mathbf{0 . 4}$ & 1 & $\mathbf{0 . 1}$ & 1 & $\mathbf{0 . 2}$ \\
Upward patellar fixation & 10 & $\mathbf{1 . 6}$ & 7 & $\mathbf{1 . 3}$ & 16 & $\mathbf{2 . 1}$ & 14 & $\mathbf{3 . 3}$ \\
Dermoid cyst & 13 & $\mathbf{2 . 1}$ & 3 & $\mathbf{0 . 5}$ & 7 & $\mathbf{0 . 9}$ & 3 & $\mathbf{0 . 7}$ \\
Navel ill & 42 & $\mathbf{6 . 8}$ & 37 & $\mathbf{6 . 6}$ & 45 & $\mathbf{5 . 8}$ & 27 & $\mathbf{6 . 3}$ \\
Urolithiasis & 7 & $\mathbf{1 . 1}$ & 4 & $\mathbf{0 . 7}$ & 7 & $\mathbf{0 . 9}$ & 3 & $\mathbf{0 . 7}$ \\
Hip dislocation & 2 & $\mathbf{0 . 3}$ & 3 & $\mathbf{0 . 5}$ & 3 & $\mathbf{0 . 4}$ & 3 & $\mathbf{0 . 7}$ \\
Horn affections & 22 & $\mathbf{3 . 6}$ & 19 & $\mathbf{3 . 4}$ & 22 & $\mathbf{2 . 8}$ & 7 & $\mathbf{1 . 6}$ \\
Foot diseases & 49 & $\mathbf{7 . 9}$ & 47 & $\mathbf{8 . 4}$ & 67 & $\mathbf{8 . 6}$ & 32 & $\mathbf{7 . 4}$ \\
Fracture & 3 & $\mathbf{0 . 5}$ & 2 & $\mathbf{0 . 4}$ & 0 & $\mathbf{0 . 0}$ & 1 & $\mathbf{0 . 2}$ \\
Myiasis & 34 & $\mathbf{5 . 5}$ & 26 & $\mathbf{4 . 6}$ & 32 & $\mathbf{4 . 1}$ & 18 & $\mathbf{4 . 2}$ \\
Humpsore & 5 & $\mathbf{0 . 8}$ & 4 & $\mathbf{0 . 7}$ & 6 & $\mathbf{0 . 8}$ & 4 & $\mathbf{0 . 9}$ \\
Arthritis & 23 & $\mathbf{3 . 7}$ & 18 & $\mathbf{3 . 2}$ & 20 & $\mathbf{2 . 6}$ & 25 & $\mathbf{5 . 8}$ \\
Tail gangrene & 2 & $\mathbf{0 . 3}$ & 0 & $\mathbf{0 . 0}$ & 0 & $\mathbf{0 . 0}$ & 1 & $\mathbf{0 . 2}$ \\
Wounds & 28 & $\mathbf{4 . 5}$ & 23 & $\mathbf{4 . 1}$ & 22 & $\mathbf{2 . 8}$ & 12 & $\mathbf{2 . 8}$ \\
Gangrenous mastitis & 4 & $\mathbf{0 . 7}$ & 0 & $\mathbf{0 . 0}$ & 2 & $\mathbf{0 . 3}$ & 0 & $\mathbf{0 . 0}$ \\
Teat obstruction & 19 & $\mathbf{3 . 1}$ & 15 & $\mathbf{2 . 7}$ & 25 & $\mathbf{3 . 2}$ & 10 & $\mathbf{2 . 3}$ \\
Teat crack & 21 & $\mathbf{3 . 4}$ & 12 & $\mathbf{2 . 1}$ & $\mathbf{1 7}$ & $\mathbf{2 . 2}$ & 9 & $\mathbf{2 . 1}$ \\
\hline & & & & & & &
\end{tabular}




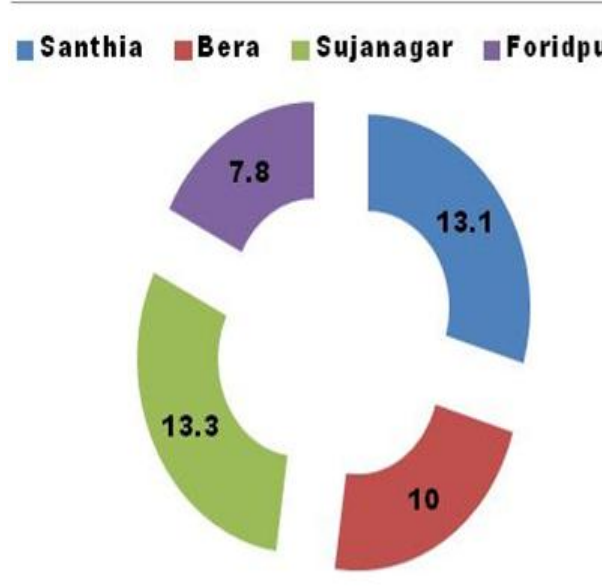

Fig. 1. Prevelernce of surgical dieases in four upazilas of Arong belt

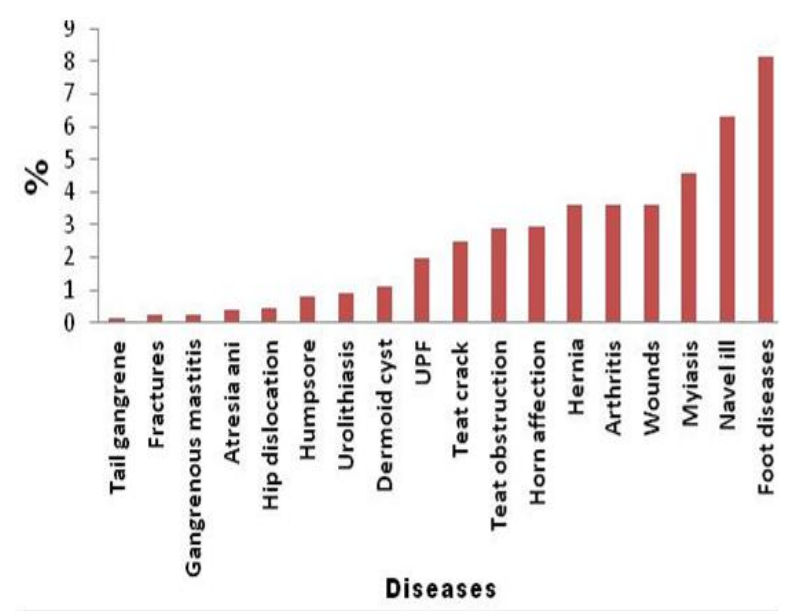

Fig. 2. Prevelence of surgical affections observed during the study

\section{Effects of sex on surgical affections in cattle}

The data on the prevalence on surgical affections of cattle in relation to sex are presented in the Table 2 and Fig. 2 . In this area, the prevalence of navel ill (11.3\%), Foot disease (11.1\%), hernia $(6.1 \%)$, horn affections $(4.9 \%)$, wounds $(4.0 \%)$ and arthritis $(3.9 \%)$, were found to be higher in male cattle compared to that in females. This finding is in consistent with the previous work of Sarkar (2012), who reported $15.07 \%$ prevalence of navel ill in PabnaSirajgonj. Whereas, the prevalence of myiasis $(5.9 \%)$ and upward patellar fixation $(2.8 \%)$ was found to be higher in females. It is important to mention that vulva and perineal region become traumatized during parturition and appear to be common sites for maggot infestation in female animals. Moreover, higher prevalence of upward patellar fixation might be related to the intensive care system, cattle breed, availability of green grass and nutrients (Sarkar, 2012).

Teat obstruction $(5.0 \%)$ and crack $(4.3 \%)$ were also higher in females as sex specific disease. The causes of treat obstruction may be due to the chronic mastitis and rough handling during milking (Gonzalez et al., 1990). Results of the present study indicate that there was strong relation between the prevalence of surgical affections and sex of animals. Overall prevalence of surgical affections was slightly higher in female in comparison to male (Fig. 3). There is significant $(\mathrm{P}<0.01)$ difference in the prevalence of hernia, upward patellar fixation, horn affection, foot diseases and myiasis between male and female.

\section{Effects of age on surgical affections in cattle}

Prevalence of surgical affections in relation to age was investigated, and Table 3 and Fig. 4 show the occurrence of surgical affections of cattle in three age groups at Aarong dairy area of Pabna. Cattle of 0-1 year was affected more frequently with surgical affections (18.7\%) among which prevalence of navel ill $(15.5 \%)$, hernia $(8.3 \%)$, myiasis $(5.4 \%)$ and foot diseases (5.3\%) were higher. Kibria (2010) reported the prevalence rate of navel ill in Bangladesh to be $6.56 \%$. Most probable cause might be the lack of proper care of newborns. Navels of new 
born calves after detachment from the umbilical cord remain raw, which become very prone to injury and infection. Cattle of 1-3 years of age affected more with foot disease (7.5\%), wounds $(6.6 \%)$, arthritis $(4.5 \%)$ and horn affections $(3.7 \%)$. Whereas, prevalence of foot disease $(12.5 \%)$ were higher, followed by teat obstruction $(9.3 \%)$, teat crack $(7.3 \%)$, horn affection $(6.0 \%)$ and upward patellar fixation $(5.1 \%)$ in cattle of more than three years of age. Moreover, significant variation $(\mathrm{P}<0.01)$ was existed in the prevalence of upward patellar fixation, foot diseases, arthritis and wounds among three age groups.

Table 2. Effect of sex on surgical affections in cattle

\begin{tabular}{|c|c|c|c|}
\hline Surgical affections & $\begin{array}{c}\text { Male \% } \\
(\mathrm{n}=1014)\end{array}$ & $\begin{array}{l}\text { Female } \% \\
(n=1376)\end{array}$ & Significant level \\
\hline Hernia & 6.1 & 1.7 & ** \\
\hline Hernia & 0.8 & 0.1 & * \\
\hline Atresia ani & 0.8 & 2.8 & $* *$ \\
\hline Upward patellar fixation & 0.9 & 1.2 & * \\
\hline Dermoid cyst & 11.3 & 2.6 & * \\
\hline Navel ill & 1.5 & 0.4 & * \\
\hline Urolithiasis & 0.0 & 0.8 & ND \\
\hline Hip dislocation & 4.9 & 1.5 & $* *$ \\
\hline Horn affection & 11.1 & 5.6 & $* *$ \\
\hline Foot diseases & 0.5 & 0.7 & * \\
\hline Fracture & 2.8 & 5.9 & ** \\
\hline Myiasis & 1.6 & 0.2 & * \\
\hline Humpsore & 3.9 & 3.3 & NS \\
\hline Arthritis & 0.3 & 0.0 & ND \\
\hline Tail gangrene & 4.0 & 3.2 & NS \\
\hline Wounds & 0.0 & 0.4 & ND \\
\hline Gangrenous mastitis & 0.0 & 5.0 & ND \\
\hline Teat obstruction & 0.0 & 4.3 & ND \\
\hline
\end{tabular}

** = significant at $1 \%$ level of probability; ${ }^{*}=$ significant at $5 \%$ level of probability; NS = not significant; $\mathrm{ND}=$ analysis not done

The prevalence of foot diseases was $(11.1 \%)$ in male and $(5.9 \%)$ in female. When data categorized according to three age groups we observed that foot disease was common in three age groups, which indicate as a common occurrence in stall feeding cattle. Sarkar (2012) has reported foot diseases $(10.85 \%)$ to be most common surgical affections install fed female. Several predisposing factors such as concrete flooring system, lack of exercise or grazing, and green mass are common in stall feeding system. The incidence of foot diseases might be related with the outbreak of foot and mouth disease, less exercise and prolong stall feeding as described by other workers (Clarkson and Ward, 1991 and Huang et al., 1995). 

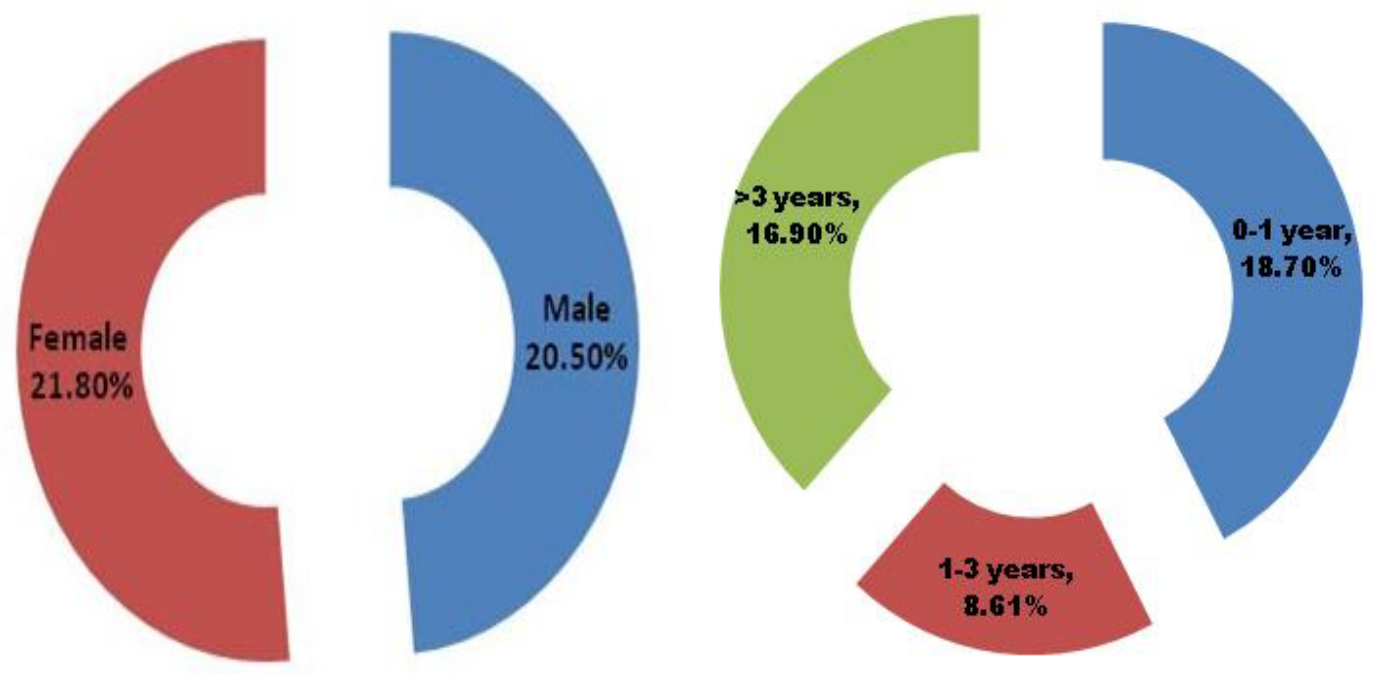

Fig. 3. Prevalence of surgical affections in male and female cattle

Fig. 4. Prevalence of surgical affections in different age groups in cattle

Table 3. Effect of age on surgical affections in cattle

\begin{tabular}{|c|c|c|c|c|}
\hline \multirow[t]{2}{*}{ Surgical affections } & \multicolumn{3}{|c|}{ Age } & \multirow[t]{2}{*}{ Significant level } \\
\hline & $\begin{array}{c}0-1 \text { years \% } \\
(\mathrm{n}=977)\end{array}$ & $\begin{array}{c}1-3 \text { years } \% \\
(\mathrm{n}=668)\end{array}$ & $\begin{array}{c}>3 \text { years } \% \\
(\mathrm{n}=745)\end{array}$ & \\
\hline Hernia & 8.3 & 0.6 & 0.0 & * \\
\hline Atresia ani & 0.9 & 0.0 & 0.0 & ND \\
\hline Upward patellar fixation & 0.0 & 1.4 & 5.1 & $* *$ \\
\hline Dermoid cyst & 2.7 & 0.0 & 0.0 & ND \\
\hline Navel ill & 15.5 & 0.0 & 0.0 & ND \\
\hline Urolithiasis & 1.5 & 0.8 & 0.1 & * \\
\hline Hip dislocation & 0.0 & 0.0 & 1.5 & ND \\
\hline Horn affection & 0.0 & 3.7 & 6.0 & * \\
\hline Foot diseases & 5.3 & 7.5 & 12.5 & $* *$ \\
\hline Fracture & 0.4 & 0.2 & 0.1 & ND \\
\hline Myiasis & 5.4 & 4.2 & 3.9 & * \\
\hline Humpsore & 0.0 & 1.4 & 1.3 & * \\
\hline Arthritis & 3.8 & 4.5 & 2.6 & $* *$ \\
\hline Tail gangrene & 0.0 & 0.2 & 0.3 & * \\
\hline Wounds & 2.1 & 6.6 & 2.8 & ** \\
\hline Gangrenous mastitis & 0.0 & 0.0 & 0.8 & ND \\
\hline Teat obstruction & 0.0 & 0.0 & 9.3 & ND \\
\hline Teat crack & 0.0 & 0.0 & 7.9 & ND \\
\hline
\end{tabular}

** = significant at $1 \%$ level of probability; * = significant at $5 \%$ level of probability; NS = not significant; $\mathrm{ND}=$ analysis not done 

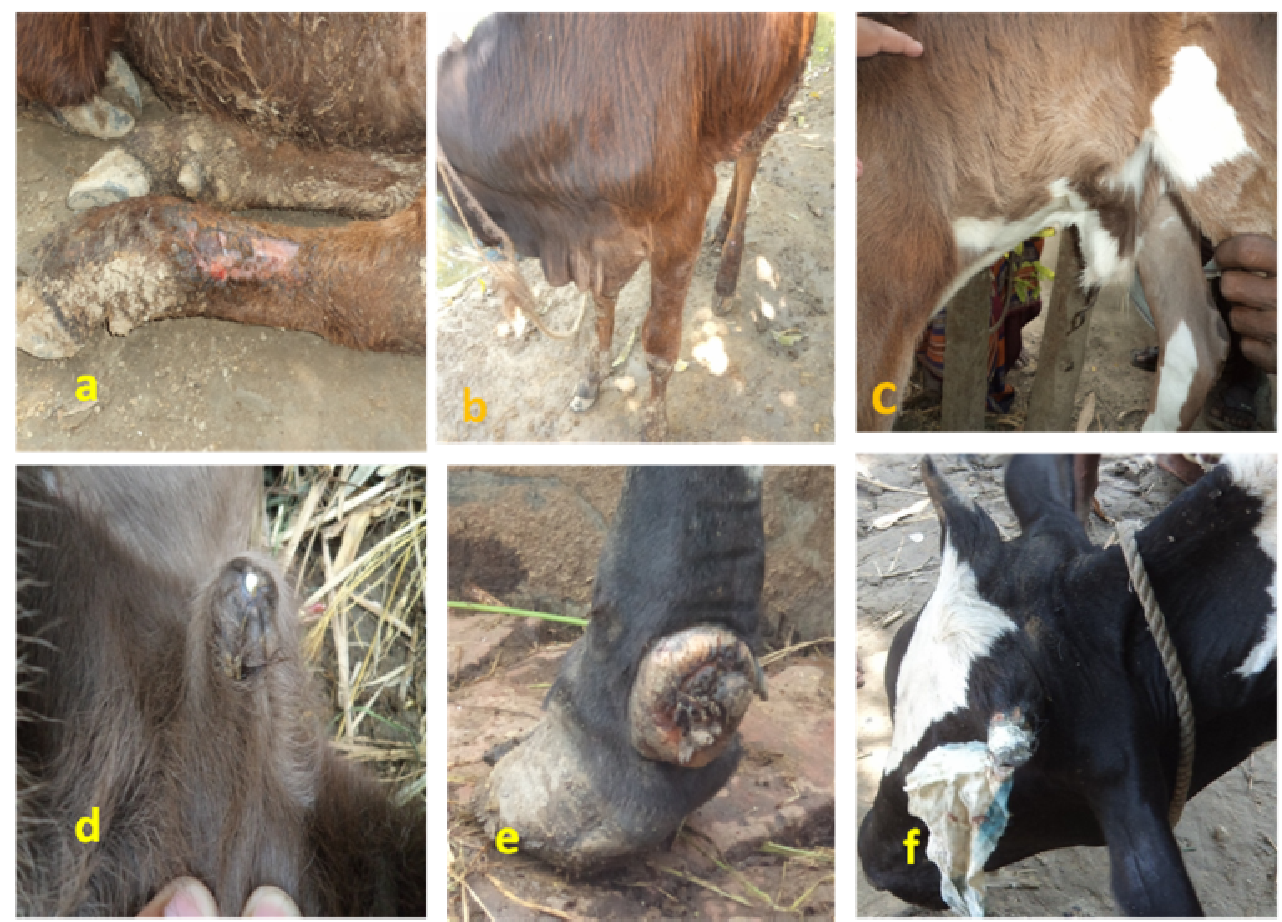

Fig. 5. a) Wounds in calf, b) arthritis in a bull, c) umbilical hernia in calf, d) naval ill in calf, e) maggot infestation and f) horn affection in cow

\section{CONCLUSIONS}

The most common cause of disability in animals are the surgical affections, which may be curable if appropriate measures are taken in time. This report on the prevalence of surgical affections of cattle in Aarong area of pabna will be an effective tool for the policy makers to determine appropriate course of action to improve the health status of cattle population. Further study is required in this area to improve the herd health.

\section{REFERENCES}

Clarkson, D. A. and Ward, W. R. 1991. Farm tracks, stockman's herding and lameness in dairy cattle. Veterinary Record, 129: 511-512.

Berge,C. and Westhues, T. S. 1986. Veterinary Operative Surgery, Denmark, Medical Book Company, Bonleverd. pp. 148.

Gonzalez, R. N., Jasper, D. E., Kronlund, N. C., Farver, T. B., Bushnell, R. B. and Ilinger, J. D. 1990. Clinical mastitis in two California dairy herds participating in contagious mastitis control programs. Journal of Dairy Science, 73: 648-660.

Hossain, M. A., Shahidullah, M. and Ali, M. A. 1986. Surgical disease and reproductive disorders recorded at the Veterinary Hospital of Bangladesh Agricultural University, Mymensingh. Bangladesh. Bangladesh Veterinary Journal, 20: 1-5. 
Hossain, M. B. 2011. Study on prevalence of atresia ani in calves. M. S. in Surgery, Thesis, Department of Surgery and Obstetrics, Bangladesh Agricultural University, Mymensingh-2202, Bangladesh.

Huang, J., Offer, J. E. and Hyslop, J. J. 1995. The cow and her cubicle. Proceeding of the 5th International Symposium on Disease of the Ruminant Digit. J. Br. Vet. Assoc., 7: 276-278.

Kibria, A. S., Khokon, M. S., Alam, M. M., Rahman, M. L. and Sarker, M. S. 2010. A comparative study on prevalence of various clinical diseases and disorders of cattle and goat in Pabna district. M. S. thesis, ...

Samad, M. A. 1998. Veterinary Clinician Guide. Bangladesh Agricultural University Campus, Mymensingh. Lyric-Epic Prokasoni. pp. 23-45.

Samad, M. A. 2000. Clinical Surgery. In: Veterinary Practitioner's Guide. LEP Publication, Dhaka. pp. 399-412.

Sarkar, N. U. 2012. Prevalence of surgical affections of cattle in milk vita area of Pabna-Sirajgonj. Bangladesh Agricultural University, Mymensingh.

Slatter, D. H. 1985. Text Book of small Animal Surgery, 1st edn. Edited by, W. B. Saunders Co., Philadelphia, pp. 310-311.

Sultana, S. 2011. Epidemiology of foot diseases in cattle. M. S. in Surgery Thesis, Department of Surgery and Obstetrics, Bangladesh Agricultural University, Mymensingh. pp. 35-41. 